\title{
Contact Toxicity of Insecticides and Biopesticides to Trichogramma Chilonis Ishii. (Hymenoptera: Trichogrammatidae) under Laboratory Condition
}

\section{Kartik S Nidagundi}

University of Agricultural Sciences, Dharwad

DN Kambrekar ( $\nabla$ kambrekardn@gmail.com )

University of Agricultural Sciences, Dharwad

\section{P. Mallapur}

University of Agricultural Sciences, Dharwad

\section{Research Article}

Keywords: Trichogramma chilonis, dry film residue bioassay, contact toxicity, biological control, Integrated Pest Management

Posted Date: December 8th, 2021

DOI: https://doi.org/10.21203/rs.3.rs-1091845/v1

License: (a) (i) This work is licensed under a Creative Commons Attribution 4.0 International License. Read Full License 


\section{Abstract}

Integration of insecticides and biological controls is an important tactic of Integrated Pest Management (IPM). Trichogramma chilonis is a promising natural enemy of many lepidopteran insect pests. However, this hymenopteran egg parasitoid is adversely affected by most insecticides. Contact toxicity of nineteen insecticides and three biopesticides on adults of $T$. chilonis was investigated by using dry film residue bioassays under laboratory conditions. Profenofos and chlorpyrifos were highly lethal to the adults even at sublethal doses followed by dimethoate, spinosad, indoxacarb and acephate + imidacloprid. Diafenthiuron, nimbecidine and flubendiamide were categorised as less toxic. The biopesticides viz., Metarhizium anisopliae, Beauveria bassiana and Metarhizium rileyi were found innocuous to T. chilonis. The studysuggests that the insecticides with less toxicity and biopesticides with apparently no harmful effects on the parasitoid can be used in conjunction with parasitoids in IPM programmes. This will also advice the plant protectionists in avoiding the one with detrimental effects on this hymenopteran wasp with appropriate timing of application that controls the pests without adversely affecting their natural enemies

\section{Introduction}

Mass breeding and release of natural enemies for control of various insect pests is now commercial practice in many countries. Trichogrammatid (Hymenoptera) egg parasitoids are distributed worldwide and represents around 80 genera from the Trichogrammatidae family with over 800 species (Sumer et al., 2009).

Trichogrammatids are considered to be the most useful biological control agents for inundative release which parasitizes the eggs of over 400 species belonging to at least seven insect orders (Bao and Chen, 1989). These egg parasitoids are of immense significance in the biological control of lepidopteran insect pests infesting several crops, preventing the insects from reaching the larval stage that cause severe damage to crops resulting reduction in the yields (Smith, 1996). Their wide distribution in different geographical areas and the ease of laboratory multiplication facilitated their employment in augmenting the biological insect pest control programmes worldwide (Parra, 2010).

Trichogramma chilonis Ishii. is an important egg parasitoid used in cotton, sugarcane, rice and other crop ecosystems which showed an appreciable success in suppressing the pest densities. The natural enemies do not eliminate the pest population completely; instead, they establish equilibrium with insect pest population that are generally below damage thresholds resulting into damage below the threshold levels. When the pest densities exceed these thresholds, an occasional insecticide treatment is needed. Natural enemies have strong tendency of susceptibility to insecticides as compared to their herbivore host/prey. The differential susceptibility of natural enemies to insecticides creates serious compatibility problems for integration of pesticides and natural enemies in IPM programmes.

The application of pesticides on a field with natural enemies of crop pests is often critical. Trichogramma spp. are directly affected by contact with the treated surface of plant during foraging, feeding on contaminated water or honey dew available on plant surfaces or while searching for mate. They also indirectly affected, since during their immature stages they live and feed inside the host eggs, along with direct effects, pesticides also affect secondary important biological traits of parasitoids, including parasitization potential, adult longevity, female to male ratio and adult emergence (Firake and Khan, 2010; Croft, 1990; Desneuxet al., 2007). It may also 
affect searching behaviour, intraspecific communication and courtship. Therefore, more selective chemicals are required to improve the ecological system service by conserving those beneficial organisms (Jacas and Urbaneja, 2009).

To date, only little is known about the toxicity risks of only few insecticides used in pest management on $T$. chilonis. We exhaustively studied 12 new generation insecticides with varied mode of action; 3 conventional insecticides which are very commonly used in the IPM programmes; 3 insecticide combi products with different mode of action; one botanical formulation and three microbial pesticides for the toxicity effects to T. chilonis under laboratory condition for the exposed generation. We also studied the impact of the insecticides at their sublethal doses (half and one fourth of the recommended doses for pest management) so as to understand the toxicity to the parasitoid.

\section{Methods}

The present investigations on the toxic effect of different insecticides and biopesticides to egg parasitoid Trichogramma chilonis was undertaken at Biocontrol Laboratory, Department of Agricultural Entomology, University of Agricultural Sciences (UAS), Dharwad, Karnataka (India) during 2020.

\section{Insects}

The egg parasitoid T. chilonis used in the present study was mass cultured using its factious host Corcyra cephalonica Stainton (Lepidoptera: Pyralidae).The host eggs were glued on paper cards $(15 \times 10 \mathrm{~cm})$ with acacia gum and killed by UV radiation before they were exposed to parasitoids. These egg cards were placed in a polythene cover along with nucleus culture of $T$. chilonis parasitised eggs of Corcyra (6:1) for $24 \mathrm{~h}$. After the exposure, cards were transferred to other polythene bag and a cotton swab that had been dipped into a 10-15\% honey solution as food for emerging parasitoids. Host and the parasitoid were maintained in laboratory at $25 \pm$ $1{ }^{\circ} \mathrm{C}$ and $70 \pm 10 \%$ relative humidity.

\section{Insecticides}

Commercial formulations of nineteen insecticides with different chemical classes and three biopesticides which were extensively used in agricultural practices to manage insect pests were selected for the bioassay. Insecticide stock solutions were prepared in beaker using acetone and water in the ratio of 80:20 and biopesticides were prepared in water at required concentrations (Table-1).

\section{Description of insecticides used in the experiment}




\begin{tabular}{|c|c|c|c|c|}
\hline Insecticides & Chemical class & Mode of action & Trade name & Manufacturer \\
\hline Spinetoram 12SC & Spinosyn & $\begin{array}{l}\text { Nicotinic } \\
\text { acetylcholine } \\
\text { receptor allosteric } \\
\text { activator }\end{array}$ & Delegate & $\begin{array}{l}\text { Dow } \\
\text { Agrosciences } \\
\text { India Pvt. Ltd. }\end{array}$ \\
\hline Spinosad 45 SC & Spinosyn & $\begin{array}{l}\text { Nicotinic } \\
\text { acetylcholine } \\
\text { receptor allosteric } \\
\text { activator }\end{array}$ & Tracer & $\begin{array}{l}\text { Dow } \\
\text { Agrosciences } \\
\text { India Pvt. Ltd. }\end{array}$ \\
\hline $\begin{array}{l}\text { Emamectin benzoate } \\
5 \mathrm{~S} \text { G }\end{array}$ & Avermectin & $\begin{array}{l}\text { Chloride channel } \\
\text { activator }\end{array}$ & Proclaim & $\begin{array}{l}\text { Syngenta India } \\
\text { Limited }\end{array}$ \\
\hline Dinotefuron 20 SG & Neonicotinoid & $\begin{array}{l}\text { Nicotinic } \\
\text { acetylcholine } \\
\text { receptor agonist }\end{array}$ & Oshin 20 SG & $\begin{array}{l}\text { Biostadt India } \\
\text { Limited }\end{array}$ \\
\hline Acetamiprid 20 SP & Neonicotinoid & $\begin{array}{l}\text { Nicotinic } \\
\text { acetylcholine } \\
\text { receptor agonist }\end{array}$ & Manik & $\begin{array}{l}\text { Rallis India } \\
\text { Limited }\end{array}$ \\
\hline Imidachloprid 17.8 SL & Neonicotinoid & $\begin{array}{l}\text { Nicotinic } \\
\text { acetylcholine } \\
\text { receptor agonist }\end{array}$ & Tatamida & $\begin{array}{l}\text { Rallis India } \\
\text { Limited }\end{array}$ \\
\hline Thiamethoxam 25 WG & Neonicotinoid & $\begin{array}{l}\text { Nicotinic } \\
\text { acetylcholine } \\
\text { receptor agonist }\end{array}$ & Actara & $\begin{array}{l}\text { Syngenta India } \\
\text { Limited }\end{array}$ \\
\hline Indoxacarb 14.5 SL & Oxadiazine & $\begin{array}{l}\text { Voltage dependent } \\
\text { sodium channel } \\
\text { blocker }\end{array}$ & Kento & $\begin{array}{l}\text { Hyderabad } \\
\text { Chemical Private } \\
\text { Limited }\end{array}$ \\
\hline Diafenthiuron 50 WP & Thiourea derivative & $\begin{array}{l}\text { Inhibitors of } \\
\text { mitochondrial ATP } \\
\text { synthase }\end{array}$ & Pegasus & $\begin{array}{l}\text { Syngenta India } \\
\text { Limited }\end{array}$ \\
\hline $\begin{array}{l}\text { Chlorantraniliprole } \\
18.5 \text { SC }\end{array}$ & Anthranilic diamide & $\begin{array}{l}\text { Ryanodine receptor } \\
\text { modulator }\end{array}$ & Coragen & $\begin{array}{l}\text { FMC India Pvt } \\
\text { Ltd }\end{array}$ \\
\hline $\begin{array}{l}\text { Cyantraniliprole } 10.26 \\
\text { OD }\end{array}$ & Anthranilic diamide & $\begin{array}{l}\text { Ryanodine receptor } \\
\text { modulator }\end{array}$ & Benevia & $\begin{array}{l}\text { DuPont india } \\
\text { Private Limited }\end{array}$ \\
\hline Dimethoate $30 \mathrm{EC}$ & Organophosphate & $\begin{array}{l}\text { Inhibition of } \\
\text { acetylcholinesterase } \\
\text { enzyme }\end{array}$ & Rogor & $\begin{array}{l}\text { FMC India Pvt } \\
\text { Ltd }\end{array}$ \\
\hline Chlorpyrifos 20 EC & Organophosphate & $\begin{array}{l}\text { Inhibition of } \\
\text { acetylcholinesterase } \\
\text { enzyme }\end{array}$ & Dhanvan-20 & $\begin{array}{l}\text { DhanukaAgritech } \\
\text { Limited }\end{array}$ \\
\hline Profenofos 50 EC & Organophosphate & $\begin{array}{l}\text { Inhibition of } \\
\text { acetylcholinesterase } \\
\text { enzyme }\end{array}$ & Jashn & $\begin{array}{l}\text { Rallis India } \\
\text { Limited }\end{array}$ \\
\hline Flubendiamide $480 \mathrm{SC}$ & $\begin{array}{l}\text { Phthalic acid } \\
\text { diamide }\end{array}$ & $\begin{array}{l}\text { Ryanodine receptor } \\
\text { modulator }\end{array}$ & Fame & $\begin{array}{l}\text { Bayer Crop } \\
\text { Science Limited }\end{array}$ \\
\hline $\begin{array}{l}\text { Chlorantraniliprole } \\
(10 \%) \text { + Lambda }\end{array}$ & $\begin{array}{l}\text { Anthranilic diamide } \\
+ \text { synthetic }\end{array}$ & $\begin{array}{l}\text { Ryanodine receptor } \\
\text { modulator + }\end{array}$ & Ampligo & $\begin{array}{l}\text { Syngenta India } \\
\text { Limited }\end{array}$ \\
\hline
\end{tabular}




\begin{tabular}{|c|c|c|c|c|}
\hline $\begin{array}{l}\text { cyhalothrin (5\%) } 150 \\
\text { ZC }\end{array}$ & pyrethroid & $\begin{array}{l}\text { Sodium channel } \\
\text { modulators }\end{array}$ & & \\
\hline $\begin{array}{l}\text { Thiamethoxam (12.6 } \\
\%)+ \text { Lambda } \\
\text { cyhalothrin (9.5\%) } 247 \\
\text { ZC }\end{array}$ & $\begin{array}{l}\text { Neonicotinoid }+ \\
\text { synthetic pyrethroid }\end{array}$ & $\begin{array}{l}\text { Nicotinic } \\
\text { acetylcholine } \\
\text { receptor agonist + } \\
\text { Sodium channel } \\
\text { modulators }\end{array}$ & Alika & $\begin{array}{l}\text { Syngenta India } \\
\text { Limited }\end{array}$ \\
\hline $\begin{array}{l}\text { Acephate }(50 \%)+ \\
\text { Imidacloprid (1.8\%) SP }\end{array}$ & $\begin{array}{l}\text { Organophosphate + } \\
\text { Neonicotinoid }\end{array}$ & $\begin{array}{l}\text { Inhibition of } \\
\text { acetylcholinesterase } \\
\text { enzyme +Nicotinic } \\
\text { acetylcholine } \\
\text { receptor agonist }\end{array}$ & Lancergold & $\begin{array}{l}\text { UPL India Pvt. } \\
\text { Ltd. }\end{array}$ \\
\hline Azadirachtin $0.03 \%$ & Tetranortriterpenoide & $\begin{array}{l}\text { Antifeedant, } \\
\text { repellent, } \\
\text { oviposition deterrent } \\
\text { and insect growth } \\
\text { regulator }\end{array}$ & Nimbecidine & $\begin{array}{l}\text { T. Stanes and } \\
\text { Company } \\
\text { Limited }\end{array}$ \\
\hline Metarhiziumanisopliae & Biopesticide & $\begin{array}{l}\text { Penetrate insect } \\
\text { cuticle }\end{array}$ & - & UAS, Dharwad \\
\hline Beauveria bassiana & Biopesticide & $\begin{array}{l}\text { Penetrate insect } \\
\text { cuticle }\end{array}$ & - & UAS, Dharwad \\
\hline Metarhiziumrileyi & Biopesticide & $\begin{array}{l}\text { Penetrate insect } \\
\text { cuticle }\end{array}$ & - & UAS, Dharwad \\
\hline
\end{tabular}

\section{Dry film residue method}

Glass test tubes of $20 \times 3.2 \mathrm{~cm}$ size with $100 \mathrm{ml}$ capacity were cleaned by soaking overnight in soap water and rinsed with acetone and air dried for at least 4 hours before use. Field recommended dose, half and one fourth of the field recommended dose of insecticides solutions were prepared and $0.5 \mathrm{ml}$ of solution or suspension was pipetted out into the glass test tube, which was later constantly rotated and rolled on a flat surface so as to form a thin and uniform coating inside the wall of test tube. Each test tube was taken as a replicate with 3 such replications per treatment and for the untreated control $0.5 \mathrm{ml}$ of acetone and distilled water in the ratio of 80:20 was used. Twenty freshly emerged (5 hours old) adult parasitoids were transferred into each test tube using a small aspirator. Then tubes were covered with muslin cloth which was secured by rubber band. A streak of honey (50\%) (Dabur) provided on the walls of tubes served as food for the parasitoids during 4 hours of exposure (Preetha et al., 2009). After 4 hours of exposure, the wasps were placed in a clean test tube and the mortality was recorded at 24 and 48 hours after treatment (HAT). The per cent adult mortality was calculated with the following formula:

$$
\mathrm{M}=\frac{\mathrm{d}}{\mathrm{n}} \times 100
$$

Where, $M=$ Per cent adult mortality; $d=$ Number of wasps died after 24 hours and $n=$ Total number of released adults.

Mortality in treatments was corrected by following formula (Abbott 1925). 
$\mathrm{Mc}=\frac{(\mathrm{M}-\mathrm{C})}{(100-\mathrm{C})} \times 100$

Where, $\mathrm{Mc}=$ Corrected mortality; $\mathrm{M}=$ Per cent mortality and $\mathrm{C}=$ Observed per cent mortality in control treatment.

According to the International Organization for Biological Control (IOBC) toxicity class, insecticides were classified based on the per cent adult mortality (Sterk et al., 1999). Per cent reduction in mortality over field recommended concentrations when the concentrations were reduced to $1 / 2$ and $1 / 4^{\text {th }}$ of the field recommended concentration was also calculated using the following formula:

Reduction in mortality $(\%)=\frac{(\mathrm{M}-\mathrm{Mx})}{(\mathrm{M})} \times 100$

Where, $M=$ Per cent mortality in the field recommended concentration and $M x=$ Per cent mortality in $1 / 2$ or $1 / 4$ th of the recommended concentration

\section{Data analysis}

The experiment was conducted in a Completely Randomized Design (CRD) and all percentage data was subjected to arc sine transform for analysis. The mean values of treatments were then subjected to Duncan's Multiple Range Test (DMRT) (Gomez and Gomez., 1984).

\section{Results}

The contact toxicity of nineteen insecticides belonging to different classes and three biopesticides at their field recommended dose (C1), half (C2) and one fourth of the recommended (C3) dose to adults of T. chilonis was tested by residue film bioassay. The lethal effects of different insecticides to $T$. chilonis were recorded in terms of adult mortality at 24 and 48 hours after treatment (HAT), after making necessary correction by Abbott's formula.

All the tested insecticides at their field recommended concentrations were significantly toxic to T. chilonis at 24 HAT(Table 1). Among the organophosphates, chlorpyrifos and profenofos were highly lethal to the parasitoids with cent per cent mortality followed by dimethoate (97.78\%) when exposed at field recommended concentrations (FRCs). Chlorpyrifos and profenofos followed the same trend when the concentrations were reduced to half and one fourth of the FRC by causing more than 92.00 per cent deaths in adults(Table 1). The per cent adult mortality values of neonicotinoids ranged between 80.95 to 95.24 at FRCs(Table 1). Among the four neonicotinoids tested thiamethoxam and imidacloprid exhibited highest toxicity with 95.24 and 90.48 per cent adult mortality and relatively less toxicity was observed in acetamiprid (80.95\%)(Table 1). At half and one fourth of the FRC, thiamethoxam found detrimental with 92.86 and 59.52 per cent mortality, respectively(Table 1).

Spinosyns like spinosad and spinetoram caused 97.78 and 91.67 per cent adult mortality respectively at FRCs and caused more than 65.00 per cent mortality at half and one fourth of the FRC. Among the three diamides, flubendiamide and chlorantraniliprole found relatively safe with 64.29 and 73.33 per cent mortality at FRC compared to cyantraniliprole (84.44\%)(Table 1). At half and one fourth FRC, chlorantraniliprole showed 
significant decrease in the mortality to 57.78 and 35.56 per cent, respectively. Indoxacarb and acephate + imidacloprid also found lethal with 97.78 per cent mortality followed by thiamethoxam + lambda-cyhalothrin (91.67\%) and chlorantraniliprole + lambda-cyhalothrin (87.18\%) at FRC and recorded more than 60.00 per cent mortality at their sublethal doses(Table 1). Diafenthiuron belonging to thiourea group recorded significantly least mortality of 61.90 per cent and was statistically on par with nimbecidine $(64.58 \%)$ at FRCs and showed drastic reduction in the mortality when the concentrations were reduced to half and one fourth of the FRCs(Table 1). Biopesticides like Metarhizium rileyi, Beauveria bassiana and Metarhizium anisopliae found safe at FRCs and even at reduced concentrations(Table 1).

We studied the toxicity of insecticides at their reduced concentration so as to know the toxicity on the parasitoid. Reduction rate in the toxicity of insecticides following reduction in the dose of insecticides was witnessed with nimbecidine and dinotefuran which imparted drastic reduction in the deaths of adults to the tune of 25.80 and 25.00 per cent respectively at 24 HAT when half of the FRCs were tested (Fig. 1a). Whereas, acephate + imidacloprid reported least reduction in the parasitoid mortality of 2.30 per cent. When the concentrations were reduced to one fourth of the FRCs, nimbecidine and chlorantraniliprole showed 54.84 and 51.52 per cent reduction in the mortality(Fig. 1a). Though there was a reduction in the dose to 50 per cent and 75 per cent of the FRCs, profenofos and chlorpyrifos recorded less than 10 per cent reduction in the parasitoid mortality indicating their high toxicity even at lower concentrations (Fig. 1a).

The toxicity of insecticides was significant on the adults of T. chilonis at 48 HAT(Table 2). Profenofos and chlorpyrifos consistently recorded cent per cent mortality in all the observed concentrations and dimethoate caused 100 per cent mortality at FRC and gradually showed decrease in the mortality at sublethal doses(Table 2). Spinosad and spinetoram recorded 100 and 94.44 per cent mortality at FRC and spinosad exhibited the same toxicity at half of the FRC(Table 2). Among neonicotinoids thiamethoxam found toxic to parasitoids with 96.97 per cent mortality at FRC and 93.94 and 60.61 per cent mortality at half and one fourth of the FRC(Table 2). Combi products thiamethoxam + lambda-cyhalothrin and chlorantraniliprole + lambda-cyhalothrin killed 96.67 per cent of the parasitoids at FRCs and at half and one fourth of the FRCs they caused the mortality in the range of 63.33 to 90.00 per cent(Table 2). Diafenthiuron and nimbecidine found relatively safe with 69.70 and 69.44 per cent mortality at FRCs and reduced the mortality of T. chilonis significantly at their sublethal doses(Table 2). However, M. anisopliae, B. bassiana and M. rileyi were the safest treatments with less than 20.00 per cent adult mortality at all the concentrations tested(Table 2).

According to Fig. 1b, when the concentrations of the insecticides were decreased to 50 per cent of the FRCs, dinotefuron reduced the mortality to 25.00 per cent but chlorpyrifos and profenofos showed no deviation in the reduction in the mortality of parasitoids even the concentration was reduced to one fourth of the FRC. However, nimbecidine reduced the mortality by 52.00 per cent when the FRC $\left(C_{1}\right)$ was reduced to $C_{3}($ Fig. 1 b).

Based on the results of mean per cent adult mortality at 24 and $48 \mathrm{hrs}$ after treatment, all the tested insecticides at their recommended concentrations were classified according to IOBC classification (Fig. 2). Chlorpyrifos and profenofos were categorized as harmful to adults of $T$. chilonis as they caused 100 per cent mortality. Dimethoate, thiamethoxam, indoxacarb, imidacloprid, spinosad, spinoteram, acephate + imidacloprid, acetamiprid, cyantraniliprole, dinotefuran, chlorantraniliprole + lambda cyhalothrin and thiamethoxam + lambda cyhalothrin were classified as moderately harmful with mean per cent mortality ranging from 82.14 to 
98.89 per cent (Fig. 2). Among the newer insecticides, emamectin benzoate, diafenthiuron, chlorantraniliprole, flubendiamide and a botanical insecticide nimbecidine were ranked as slightly harmful. Microbial pesticides were under the category of harmless insecticides to T. chilonis (Fig. 2).

\section{Discussion}

The application of pesticides on a field with natural enemies of crop pests is often critical as the natural enemies are directly affected by the insecticide treated surface of plants during foraging, feeding on contaminated water or honey dew available on plant surfaces or while searching their mates. Therefore, it is crucial to assess the impact of pesticides on natural enemies like parasitoids. Hazardous nature of the insecticides on the parasitoids were studied based on the mortality caused by the insecticide residues when the parasitoid adults were exposed and they were categorized from harmless to harmful according to IOBC toxicity classes.

We studied nineteen insecticides and three biopesticides against adults of $T$. chilonis. All the tested chemicals insecticides imparted serious impacts when applied at their maximum recommended field doses and some insecticides exhibited safety towards the parasitoids. This information could provide a reference for the determination of safer chemicals which can be used in conjunction with the T. chilonis in IPM programmes, on different crops.

Organophosphates like profenofos and chlorpyrifos are highly toxic and non- selective due to their ability to inactivate acetylcholine esterase (Carmo et al., 2010), causing loss of available acetylcholinesterase and over stimulation of organs by excessive acetylcholine at the nerve endings and these effects are similar on both pests and natural enemies (Fukuto, 1990). The lethal effects of profenofos against T. chilonis (Kumar et al., 2013) and chlorpyrifos against Trichogramma achaeae Nagaraja and Nagarkatti (Fontes et al., 2018) are well documented which caused 100 per cent mortality of adults. Neonicotinoidsserves as a competitive inhibitor of the nicotinic acetylcholine receptors (nAChRs) in the insect central nervous system and effective chemicals used for the control of chewing and sucking pests (Tomizawa and Casida, 2003). Identically thiamethoxam, a well known broad spectrum neonicotinoid was found toxic to $T$. chilonis by showing complete mortality of adult parasitoids at 24 HAT (Kumar et al., 2013). Spinosad is a macrocyclic lactone from the actinomycete, Saccharopolyspora spinosa which primarily act asa stomach poison and also with some contact activity (Bret et al., 1997). Nevertheless, it is a safe insecticide to predators but hymenopteran parasitoids are significantly more susceptible to spinosad (William et al., 2004). Significantly higher mortality of Trichogramma spp was reported by Suh et al. (2000), Saljoqi et al. (2012) and Uma et al. (2014) when exposed to spinosad residues.

The present study inferred that diafenthiuron and nimbecidine as relatively safe to $T$. chilonis and it was supported by Mahankunda et al. (2019) who reported that diafenthiuron caused 30.66 per cent mortality and azadirachtin concentration caused 10.26 per cent mortality of T. chilonis. Flubendiamide caused 55.27 per cent mortality of T. chilonis at recommended field concentration (Uma et al., 2014). Tohnishi et al. (2005) proved that flubendiamide was very safe to natural enemies. M. anisopliae and B. bassiana were harmless to T.pretiosum(Amaro et al., 2015) and safe to Cotesia flavipes (Rassoni et al., 2014).

Pyrethroids have distinct mode of action which bind to the receptor site on the sodium channel in insects and extend the open state by inactivation and inhibiting the channel deactivation (Vais et al., 2001). As lambda- 
cyhalothrin is one of the components in the combi products used in the present study which made them toxic to the parasitoid adults. Based on the risk quotient value, it was classified as dangerous insecticides to the adults of T. chilonis (Shankarganesh et al., 2013). Chemical compounds belonging diamides group, such as flubendiamide and chlorantraniliprole act on ryanodine receptors (Ebbinghaus-Kintscher et al., 2007), which cause insect death by preventing the normal muscle contractions of the insect. These compounds are very choosy and since they act more specifically on phytophagous insects, primarily the lepidoptera order (Stecca et al. 2014). In addition, they are considered innocuous to natural enemies (Lahm et al., 2009) as they primarily act by contact through ingestion, as evidenced by our contact test with dry insecticide residues.

The very interesting observation of the present finding is that in case of profenofos and chlorpyrifos, though the concentration was reduced to half and one fourth of the recommended doses, there was no proportinate reduction in the toxicity to adults of

T. chilonis (Fig. 1). These findings clearly caution the farmers and IPM practitioners about the high toxicity of these two insecticides even at the sublethal doses. In a given crop ecosystem, where T. chilonis is a natural enemy, lower dose of the highly toxic insecticides can cause cent per cent mortality of T. chilonis. Before recommending such insecticides in any crops in the management of insect pests, their hazardous effects on $T$. chilonis should also be considered while tailoring the pest management strategies.

The present results demonstrate the effects of a various chemical compounds on Trichogramma parasitoids. The inferences of the present investigations are meaningful in selecting insecticide compatible with IPM strategies particularly the bio-control agents. The results showed high vulnerability of egg parasitoids to insecticides particularly adults and also revealed the suitability of some insecticides like chlorantraniliprole, flubendiamide, diafenthiuron, emamectin benzoate for protecting the natural populations of Trichogramma wasps. Though, under the field condition, the insecticide residues are exposed to so many degrading factors, such as wind, rain and radiation from the sun might not put so high risk on the parasitic wasps (Hewa-Kapuge et al., 2003), further studies are needed to identify the safer chemicals that can be used under field condition.

Table 1: Contact toxicity of insecticides and biopesticides on adults of T. chilonis

\section{@ 24 HAT}




\begin{tabular}{|c|c|c|c|c|c|c|c|}
\hline \multirow[t]{2}{*}{$\begin{array}{l}\text { SI. } \\
\text { No. }\end{array}$} & \multirow[t]{2}{*}{ Treatments } & \multicolumn{3}{|c|}{ Dose $(\mathrm{ml} / \mathrm{g} / \mathrm{l})$} & \multicolumn{3}{|c|}{$\begin{array}{l}\text { Mortality of adult } \\
\text { T. chilonis(\%) }\end{array}$} \\
\hline & & $\mathrm{C}_{1}$ & $\mathrm{C}_{2}$ & $\mathrm{C}_{3}$ & $\mathrm{C}_{1}$ & $\mathrm{C}_{2}$ & $\mathrm{C}_{3}$ \\
\hline 1 & Spinetoram 12 SC & 1.00 & 0.50 & 0.25 & $\begin{array}{l}91.67 \\
b\end{array}$ & $\begin{array}{l}77.08 \\
c\end{array}$ & $\begin{array}{l}68.75 \\
c\end{array}$ \\
\hline 2 & Emamectin benzoate $5 \mathrm{~S} \mathrm{G}$ & 0.20 & 0.10 & 0.05 & $\begin{array}{l}73.81 \\
d\end{array}$ & $\begin{array}{l}64.29 \\
d\end{array}$ & $\begin{array}{l}38.10 \\
\mathrm{~g}\end{array}$ \\
\hline 3 & Spinosad 45 SC & 0.20 & 0.10 & 0.05 & $\begin{array}{l}97.78 \\
a\end{array}$ & $\begin{array}{l}86.67 \\
b\end{array}$ & $\begin{array}{l}66.67 \\
c\end{array}$ \\
\hline 4 & Acetamiprid 20 SP & 0.10 & 0.05 & 0.025 & $\begin{array}{l}80.95 \\
c\end{array}$ & $\begin{array}{l}69.05 \\
d\end{array}$ & $\begin{array}{l}54.76 \\
\mathrm{e}\end{array}$ \\
\hline 5 & Dimethoate $30 \mathrm{EC}$ & 1.70 & 0.85 & 0.425 & $\begin{array}{l}97.78 \\
a\end{array}$ & $\begin{array}{l}82.22 \\
b\end{array}$ & $\begin{array}{l}77.78 \\
b\end{array}$ \\
\hline 6 & Imidacloprid $17.8 \mathrm{~S}$ & 0.20 & 0.10 & 0.05 & $\begin{array}{l}90.48 \\
b\end{array}$ & $\begin{array}{l}78.57 \\
c\end{array}$ & $\begin{array}{l}57.14 \\
\mathrm{e}\end{array}$ \\
\hline 7 & Thiamethoxam 25 WG & 0.20 & 0.10 & 0.05 & $\begin{array}{l}95.24 \\
a\end{array}$ & $\begin{array}{l}92.86 \\
\mathrm{a}\end{array}$ & $\begin{array}{l}59.52 \\
d\end{array}$ \\
\hline 8 & Indoxacarb 14.5 SL & 0.50 & 0.25 & 0.125 & $\begin{array}{l}97.78 \\
\text { a }\end{array}$ & $\begin{array}{l}86.67 \\
b\end{array}$ & $\begin{array}{l}64.44 \\
c\end{array}$ \\
\hline 9 & Diafenthiuron 50 WP & 0.60 & 0.30 & 0.15 & $\begin{array}{l}61.90 \\
\mathrm{e}\end{array}$ & $\begin{array}{l}52.38 \\
f\end{array}$ & $\begin{array}{l}40.48 \\
h\end{array}$ \\
\hline 10 & Chlorantraniliprole $18.5 \mathrm{SC}$ & 0.20 & 0.10 & 0.05 & $\begin{array}{l}73.33 \\
d\end{array}$ & $\begin{array}{l}57.78 \\
\mathrm{e}\end{array}$ & $\begin{array}{l}35.56 \\
h\end{array}$ \\
\hline 11 & Cyantraniliprole 10.26 OD & 0.90 & 0.45 & 0.225 & $\begin{array}{l}84.44 \\
c\end{array}$ & $\begin{array}{l}75.56 \\
c\end{array}$ & $\begin{array}{l}68.89 \\
c\end{array}$ \\
\hline 12 & Dinotefuron 20 SG & 0.30 & 0.15 & 0.075 & $\begin{array}{l}82.05 \\
c\end{array}$ & $\begin{array}{l}61.54 \\
\mathrm{e}\end{array}$ & $\begin{array}{l}48.72 \\
f\end{array}$ \\
\hline 13 & Chlorpyrifos 20 EC & 2.00 & 1.00 & 0.50 & $\begin{array}{l}100.00 \\
a\end{array}$ & $\begin{array}{l}97.62 \\
a\end{array}$ & $\begin{array}{l}92.86 \\
a\end{array}$ \\
\hline 14 & Profenofos $50 \mathrm{EC}$ & 2.00 & 1.00 & 0.50 & $\begin{array}{l}100.00 \\
a\end{array}$ & $\begin{array}{l}97.44 \\
\text { a }\end{array}$ & $\begin{array}{l}94.87 \\
\mathrm{a}\end{array}$ \\
\hline 15 & Flubendiamide $480 \mathrm{SC}$ & 0.20 & 0.10 & 0.05 & $\begin{array}{l}64.29 \\
\mathrm{e}\end{array}$ & $e^{59.52}$ & $\begin{array}{l}47.62 \\
f\end{array}$ \\
\hline 16 & $\begin{array}{l}\text { Chlorantraniliprole }(10 \%)+\text { Lambda- } \\
\text { cyhalothrin }(5 \%) 150 \mathrm{ZC}\end{array}$ & 0.50 & 0.25 & 0.125 & $\begin{array}{l}87.18 \\
b\end{array}$ & $\begin{array}{l}82.05 \\
b\end{array}$ & $\begin{array}{l}61.54 \\
d\end{array}$ \\
\hline 17 & $\begin{array}{l}\text { Thiamethoxam }(12.6 \%)+\text { Lambda- } \\
\text { cyhalothrin }(9.5 \%) 247 \text { ZC }\end{array}$ & 0.50 & 0.25 & 0.125 & $\begin{array}{l}91.67 \\
b\end{array}$ & $\begin{array}{l}83.33 \\
b\end{array}$ & $\begin{array}{l}63.89 \\
d\end{array}$ \\
\hline
\end{tabular}




\begin{tabular}{|c|c|c|c|c|c|c|c|}
\hline \multirow[t]{2}{*}{$\begin{array}{l}\text { Sl. } \\
\text { No. }\end{array}$} & \multirow[t]{2}{*}{ Treatments } & \multicolumn{3}{|c|}{ Dose $(\mathrm{ml} / \mathrm{g} / \mathrm{l})$} & \multicolumn{3}{|c|}{$\begin{array}{l}\text { Mortality of adult } \\
\text { T. chilonis(\%) }\end{array}$} \\
\hline & & $\mathrm{C}_{1}$ & $\mathrm{C}_{2}$ & $\mathrm{C}_{3}$ & $\mathrm{C}_{1}$ & $\mathrm{C}_{2}$ & $\mathrm{C}_{3}$ \\
\hline 18 & Acephate (50\%) + Imidacloprid (1.8\%) SP & 2.00 & 1.00 & 0.50 & $\begin{array}{l}97.78 \\
\text { a }\end{array}$ & $\begin{array}{l}95.56 \\
\text { a }\end{array}$ & $\begin{array}{l}64.44 \\
c\end{array}$ \\
\hline 19 & Nimbecidine (0.03\% Azadirachtin) & 5.00 & 2.50 & 1.25 & $\begin{array}{l}64.58 \\
\mathrm{e}\end{array}$ & $47.92^{f}$ & $i_{i}^{29.17}$ \\
\hline 20 & M. anisopliae & 2.00 & 1.00 & 0.50 & $8.89 \mathrm{~g}$ & $6.67^{\mathrm{g}}$ & $2.22^{j}$ \\
\hline 21 & B. bassiana & 8.00 & 4.00 & 2.00 & $11.11^{f}$ & $6.67^{\mathrm{g}}$ & 0.00 \\
\hline 22 & M. rileyi & 1.00 & 0.5 & 0.25 & $16.67^{f}$ & $9.52^{\mathrm{g}}$ & 0.00 \\
\hline
\end{tabular}

${ }^{*} \mathrm{C}_{1}=$ Recommended field dose, $\mathrm{C}_{2}=$ Half of the recommended field dose, $\mathrm{C}_{3}=$ One fourth of the recommended field dose.

* In column, means followed by a common letter are not significantly different at $p=0.05$ by Duncan's multiple range test (DMRT)

* The original values were subjected to arc sine transformation before analysis. 
Table 2

Contact toxicity of insecticides and biopesticides on adults of T. chilonis at 48 HAT

\begin{tabular}{|c|c|c|c|c|c|c|c|}
\hline \multirow[t]{2}{*}{$\begin{array}{l}\text { Sl. } \\
\text { No }\end{array}$} & \multirow[t]{2}{*}{ Treatments } & \multicolumn{3}{|c|}{ Dose (ml/g/l) } & \multicolumn{3}{|c|}{$\begin{array}{l}\text { Mortality of adult } \\
\text { T. chilonis (\%) }\end{array}$} \\
\hline & & $\mathrm{C}_{1}$ & $\mathrm{C}_{2}$ & $\mathrm{C}_{3}$ & $\mathrm{C}_{1}$ & $\mathrm{C}_{2}$ & $\mathrm{C}_{3}$ \\
\hline 1 & Spinetoram 12 SC & 1.00 & 0.50 & 0.25 & $\begin{array}{l}94.44 \\
\mathrm{a}\end{array}$ & $\begin{array}{l}77.78 \\
c\end{array}$ & $\begin{array}{l}69.23 \\
d\end{array}$ \\
\hline 2 & Emamectin benzoate $5 \mathrm{~S} \mathrm{G}$ & 0.20 & 0.10 & 0.05 & $\begin{array}{l}78.79 \\
c\end{array}$ & $\begin{array}{l}75.76 \\
c\end{array}$ & $\begin{array}{l}42.42 \\
g\end{array}$ \\
\hline 3 & Spinosad 45 SC & 0.20 & 0.10 & 0.05 & $\begin{array}{l}100.00 \\
a\end{array}$ & $\begin{array}{l}93.33 \\
\mathrm{a}\end{array}$ & $\begin{array}{l}69.23 \\
c\end{array}$ \\
\hline 4 & Acetamiprid 20 SP & 0.10 & 0.05 & 0.025 & $\begin{array}{l}83.33 \\
b\end{array}$ & $\begin{array}{l}69.70 \\
d\end{array}$ & $\begin{array}{l}58.33 \\
e\end{array}$ \\
\hline 5 & Dimethoate 30 EC & 1.70 & 0.85 & 0.425 & $\begin{array}{l}100.00 \\
a\end{array}$ & $\begin{array}{l}87.88 \\
b\end{array}$ & $\begin{array}{l}78.79 \\
b\end{array}$ \\
\hline 6 & Imidacloprid $17.8 \mathrm{~S}$ & 0.20 & 0.10 & 0.05 & $\begin{array}{l}93.94 \\
\mathrm{a}\end{array}$ & $\begin{array}{l}78.79 \\
c\end{array}$ & $\begin{array}{l}63.64 \\
d\end{array}$ \\
\hline 7 & Thiamethoxam 25 WG & 0.20 & 0.10 & 0.05 & $\begin{array}{l}96.97 \\
\mathrm{a}\end{array}$ & $\begin{array}{l}93.94 \\
\mathrm{a}\end{array}$ & $\begin{array}{l}60.61 \\
d\end{array}$ \\
\hline 8 & Indoxacarb 14.5 SL & 0.50 & 0.25 & 0.125 & $\begin{array}{l}100.00 \\
a\end{array}$ & $\begin{array}{l}92.31 \\
b\end{array}$ & $\begin{array}{l}66.67 \\
c\end{array}$ \\
\hline 9 & Diafenthiuron 50 WP & 0.60 & 0.30 & 0.15 & $\begin{array}{l}69.70 \\
d\end{array}$ & $\begin{array}{l}54.55 \\
\mathrm{e}\end{array}$ & $51.52^{f}$ \\
\hline 10 & Chlorantraniliprole $18.5 \mathrm{SC}$ & 0.20 & 0.10 & 0.05 & $\begin{array}{l}75.76 \\
c\end{array}$ & $\begin{array}{l}61.11 \\
\mathrm{e}\end{array}$ & $\begin{array}{l}41.03 \\
g\end{array}$ \\
\hline 11 & Cyantraniliprole 10.26 OD & 0.90 & 0.45 & 0.225 & $\begin{array}{l}88.89 \\
b\end{array}$ & $\begin{array}{l}77.78 \\
c\end{array}$ & $\begin{array}{l}69.44 \\
c\end{array}$ \\
\hline 12 & Dinotefuron $20 \mathrm{SG}$ & 0.30 & 0.15 & 0.075 & $\begin{array}{l}84.85 \\
b\end{array}$ & $\begin{array}{l}63.64 \\
d\end{array}$ & $\begin{array}{l}60.61 \\
d\end{array}$ \\
\hline 13 & Chlorpyrifos 20 EC & 2.00 & 1.00 & 0.50 & $\begin{array}{l}100.00 \\
a\end{array}$ & $\begin{array}{l}100.00 \\
a\end{array}$ & $\begin{array}{l}100.00 \\
a\end{array}$ \\
\hline 14 & Profenofos $50 \mathrm{EC}$ & 2.00 & 1.00 & 0.50 & $\begin{array}{l}100.00 \\
a\end{array}$ & $\begin{array}{l}100.00 \\
\mathrm{a}\end{array}$ & $\begin{array}{l}100.00 \\
a\end{array}$ \\
\hline 15 & Flubendiamide $480 \mathrm{SC}$ & 0.20 & 0.10 & 0.05 & $\begin{array}{l}69.44 \\
d\end{array}$ & $\begin{array}{l}61.11 \\
\mathrm{e}\end{array}$ & $\begin{array}{l}55.56 \\
\mathrm{e}\end{array}$ \\
\hline 16 & $\begin{array}{l}\text { Chlorantraniliprole }(10 \%)+\text { Lambda- } \\
\text { cyhalothrin (5\%) } 150 \mathrm{ZC}\end{array}$ & 0.50 & 0.25 & 0.125 & $\begin{array}{l}96.67 \\
\mathrm{a}\end{array}$ & $\begin{array}{l}86.67 \\
b\end{array}$ & $\begin{array}{l}63.33 \\
d\end{array}$ \\
\hline
\end{tabular}




\begin{tabular}{|c|c|c|c|c|c|c|c|}
\hline \multirow[t]{2}{*}{$\begin{array}{l}\text { SI. } \\
\text { No }\end{array}$} & \multirow[t]{2}{*}{ Treatments } & \multicolumn{3}{|c|}{ Dose $(\mathrm{ml} / \mathrm{g} / \mathrm{l})$} & \multicolumn{3}{|c|}{$\begin{array}{l}\text { Mortality of adult } \\
\text { T. chilonis (\%) }\end{array}$} \\
\hline & & $\mathrm{C}_{1}$ & $\mathrm{C}_{2}$ & $\mathrm{C}_{3}$ & $\mathrm{C}_{1}$ & $\mathrm{C}_{2}$ & $\mathrm{C}_{3}$ \\
\hline 17 & $\begin{array}{l}\text { Thiamethoxam }(12.6 \%)+\text { Lambda- } \\
\text { cyhalothrin }(9.5 \%) 247 \mathrm{ZC}\end{array}$ & 0.50 & 0.25 & 0.125 & $\begin{array}{l}96.67 \\
a\end{array}$ & $\begin{array}{l}90.00 \\
b\end{array}$ & $\begin{array}{l}70.00 \\
c\end{array}$ \\
\hline 18 & Acephate (50\%) + Imidacloprid (1.8\%) SP & 2.00 & 1.00 & 0.50 & $\begin{array}{l}100.00 \\
a\end{array}$ & $\begin{array}{l}97.22 \\
\mathrm{a}\end{array}$ & $\begin{array}{l}66.67 \\
c\end{array}$ \\
\hline 19 & Nimbecidine (0.03\% Azadirachtin) & 5.00 & 2.50 & 1.25 & $\begin{array}{l}69.44 \\
d\end{array}$ & $52.78^{f}$ & $\begin{array}{l}33.33 \\
h\end{array}$ \\
\hline 20 & M. anisopliae & 2.00 & 1.00 & 0.50 & $\begin{array}{l}13.89 \\
\mathrm{e}\end{array}$ & $\begin{array}{l}12.82 \\
g\end{array}$ & $8.33^{i}$ \\
\hline 21 & B. bassiana & 8.00 & 4.00 & 2.00 & $\begin{array}{l}16.67 \\
\mathrm{e}\end{array}$ & $\begin{array}{l}12.82 \\
g\end{array}$ & $11.11^{\mathrm{i}}$ \\
\hline 22 & M. rileyi & 1.00 & 0.5 & 0.25 & $\begin{array}{l}18.18 \\
e^{-1}\end{array}$ & 12.12 & $6.06^{j}$ \\
\hline
\end{tabular}

${ }^{*} \mathrm{C}_{1}=$ Recommended field dose, $\mathrm{C}_{2}=$ Half of the recommended field dose, $\mathrm{C}_{3}=$ One fourth of the recommended field dose

* The original values were subjected to arc sine transformation before analysis

\section{References}

1. Abbott, W. S. A method of computing the effectiveness of an insecticide. J. Am. Mosquito Control Assoc.7, 265-67(1925).

2. Bao, J., Chen, X. Research and application of Trichogramma in China. Beijing, China. Academia Books and Periodicals Science Press.220 (1989).

3. Bret, B. L., Larson, L. L., Schoonover, J. R., Sparks, T. C. \& Thompson, G. D. Biological properties of spinosad. Down to Earth.52, 6-13 (1997).

4. Carmo, E. L., Bueno, A. F. \& Bueno, R. C. O. F., Pesticide selectivity for the insect egg parasitoid Telenomus remus. Biol. Control.55, 455-464 (2010).

5. Ebbinghaus-Kintscher U, L. and Raming, K. M. N. Flubendiamide, the first insecticide with a novel mode of action on insect ryanodine receptors. Pflanzenschutz-Nachr Bayer.60, 117-140 (2007).

6. Fontes, J., Roja, I. S., Tavares, J. and Oliveira, L.Lethal and sublethal effects of various pesticides on Trichogramma achaeae (Hymenoptera: Trichogrammatidae). J. Econ. Entomol.111, 1219-1226 (2018).

7. Fukuto, T. R.Mechanism of action of organophosphorus and carbamate insecticides. Environ. Health Prospect. 87, 245-254 (1990).

8. Gomez, K. A. \& Gomez, A. A.Statistical Procedures for Agricultural Research.Wiley, New York, pp, 680 (1984). 
9. Hewa-Kapuge, S., McDougall, S. \& Hoffmann, A. A. Effects of methoxyfenozide, indoxacarb, and other insecticides on the beneficial egg parasitoid Trichogramma nr. brassicae (Hymenoptera:

Trichogrammatidae) under laboratory and field conditions. J. Econ. Entomol.96, 1083-1090 (2003).

10. Kumar, A.Assessment of biosafety of commonly used insecticides to Trichogramma chilonis Ishii, Ph. D Thesis, Institute of Agricultural Sciences, Banaras Hindu University (2013).

11. Lahm, G. P., Cordova, D. \& Barry, J. D. New and selective ryanodine receptor activators for insect control. Bioorganic Med. Chem., 17, 4127-4133 (2009).

12. Mahankuda, B., Sawai, H. R., Gawande, R. W., Neharkar, P. S. and Nagdeote, V. G.Effect of insecticide residues on the adult survival rate of Trichogramma chilonis under laboratory condition. J. Entomol. Zool. Stud.7,1349-1351 (2019).

13. Parra, J.R.P. Mass rearing of egg parasitoids for biological control programs. In: Consoli, F.L., Parra, J.R.P., Zucchi, R.A. (Eds.), Egg Parasitoids in Agroecosystems with Emphasis on Trichogramma. Springer, Dordrecht, pp. $267 \mathrm{e} 278$ (2010).

14. Preetha, G., Stanley, J., Suresh, S. and Kuttalum, S.Toxicity of selected insecticides to Trichogramma chilonis, Assessing their safety in the rice ecosystem. Phytoparasitica.3, 209-215(2009).

15. Rassoni, C. et al. Metarhizium anisopliae and Beauveria bassiana (Hypocreales: Clavicipitaceae) are compatible with Cotesia flavipes (Hymenoptera: Braconidae). Fla. Entomol.,63, 1794-1804(2014).

16. Saljoqi, A., Nawaz, M., Farid, A. \& Khan, I. A. Compatibility of spinosad with Trichogrammachilonis(Hymenoptera: Trichogrammatidae) in integrated pest management in Sitotrogacereallela. Pak. J. Zool.44, 133-139(2012).

17. Shankarganesh, K., Paul, B. \& Gautam, R. D.Studies on ecological safety of insecticides to egg parasitoids, Trichogramma chilonis Ishii and Trichogramma brasiliensis (Ashmead). Nat. Acad. Sci. Letters, 36, 581-585 (2013).

18. Smith, S. M. Biological control with Trichogramma, Advances, successes and potential of their use. Annu. Rev. Entomo, 41(1)375-406 (1996).

19. Stecca, C. D. S., Bueno, A. D. F., Denez, M., da Silva, D. M. \& Montovani, M. Insecticide selectivity for Dorulineare (Dermaptera: Forficulidae). RevistaBrasileira de Milho e Sorgo. 13, 107-115 (2014).

20. Sterk, G.et al. Results of the seventh joint pesticide testing programme carried out by the IOBC/WPRSWorking Group 'Pesticides and Beneficial Organisms'. Biol. Control.44, 99-117 (1999).

21. Suh, C. P. C., Orr, D. B. \& Van, D. J. W.Effect of insecticides on Trichogramma exiguum (Trichogrammatidae: Hymenoptera) preimaginal development and adult survival. J. Econ. Entomol.93, 577-583 (2000).

22. Sumer, F.et al.A molecular key to the common species of Trichogramma of the Mediterranean region. Biol. Control.54, 617-624 (2009).

23. Tohnishi, M.et al. Flubendiamide, a novel insecticide highly active against lepidopterous insect pests. J. Pestic. Sci.30, 354-360 (2005).

24. Tomizawa, T. M. \& Casida, J. E.Selective toxicity of neonicotinoids attributable to specificity of insect and mammalian nicotinic receptors. Annu. Rev. Entomol.48,339-364 (2003).

25. Vais, H., Williamson, M. S., Devonshire, A. L. \& Usherwood, P. N. R. The molecular interactions of pyrethroid insecticides with insect and mammalian sodium channels. Pest. Manag. Sci.57, 877-888 (2001). 
26. Williams, L. \& Price, L.A space-efficient contact toxicity bioassay for minute Hymenoptera, used to test the effects of novel and conventional insecticides on the egg parasitoids Anaphesiole and Trichogramma pretiosum. Biol. Control. 49, 163-185 (2004)

\section{Figures}
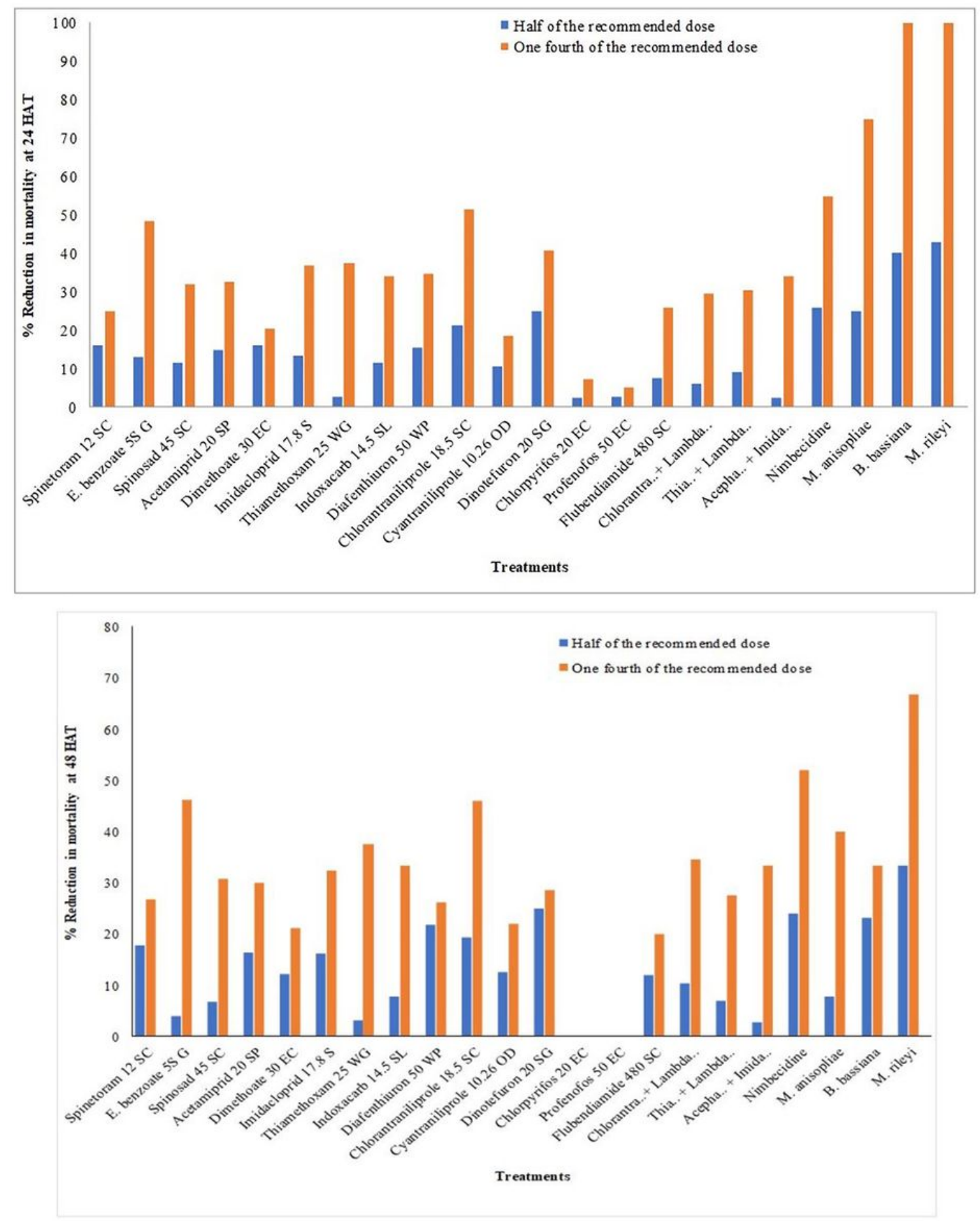

Figure 1

Please see the Manuscript file for the complete figure caption. 


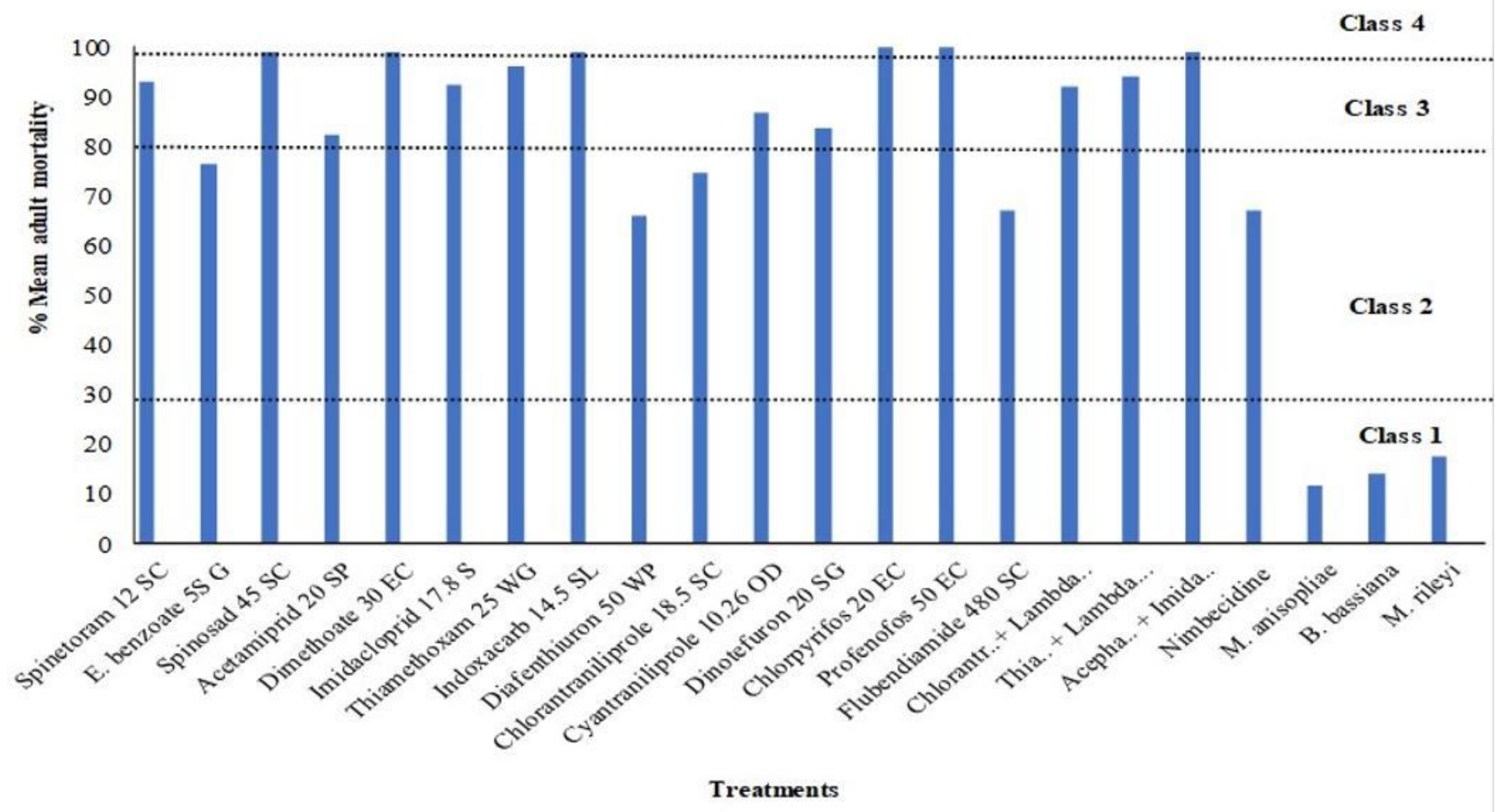

Figure 2

Please see the Manuscript file for the complete figure caption. 